\section{Climate burden of refrigerants rockets}

\section{Environmentalists push for tougher regulation of chemicals meant to help the ozone layer.}

Modern refrigerants designed to protect the ozone layer are poised to become a major contributor to global warming because of their future explosive growth in the developing world, scientists report this week.

Hydrofluorocarbon chemicals (HFCs) were developed to phase out ozone-depleting gases, in response to the Montreal Protocol. But they can be hundreds or thousands of times more powerful than carbon dioxide as greenhouse gases in trapping heat. HFCs are deployed in refrigerators and

\section{"Now is the moment to make a decision to steer this in a direction that you want."}

continue to rise unchecked (G. J. M. Velders et al. Proc. Natl Acad. Sci. USA doi:10.1073. pnas.0902817106; 2009).

The new numbers will fuel the efforts of environmentalists and others who have been pushing for aggressive new HFC regulations. Manufacturers could shift towards using HFCs with the lowest climate impact during the transition to a new generation of refrigerants still under development that affect neither the ozone layer nor the climate.

"Now is the moment to air-conditioning units, and their use is poised to grow in the coming decades.

In the new study, a team led by Guus Velders at the Netherlands Environmental Assessment Agency in Bilthoven analysed the latest industry trends and then modelled HFC production to 2050. Their results suggest that HFC emissions could be the equivalent of between 5.5 billion and 8.8 billion tonnes of carbon dioxide annually by 2010 - roughly $19 \%$ of the projected $\mathrm{CO}_{2}$ emissions if greenhouse gases make a decision to steer this in a direction that you want," Velders says. “The developing world is already in the transition to HFCs."

Although it makes no policy recommendpolitical debate on regulating the chemicals. HFCs currently fall under the umbrella of the Kyoto Protocol on climate change, but advocates say the fastest and cheapest way to handle them is under the ozone treaty. Montreal delegates plan to discuss the issue ations, the study could play into an ongoing

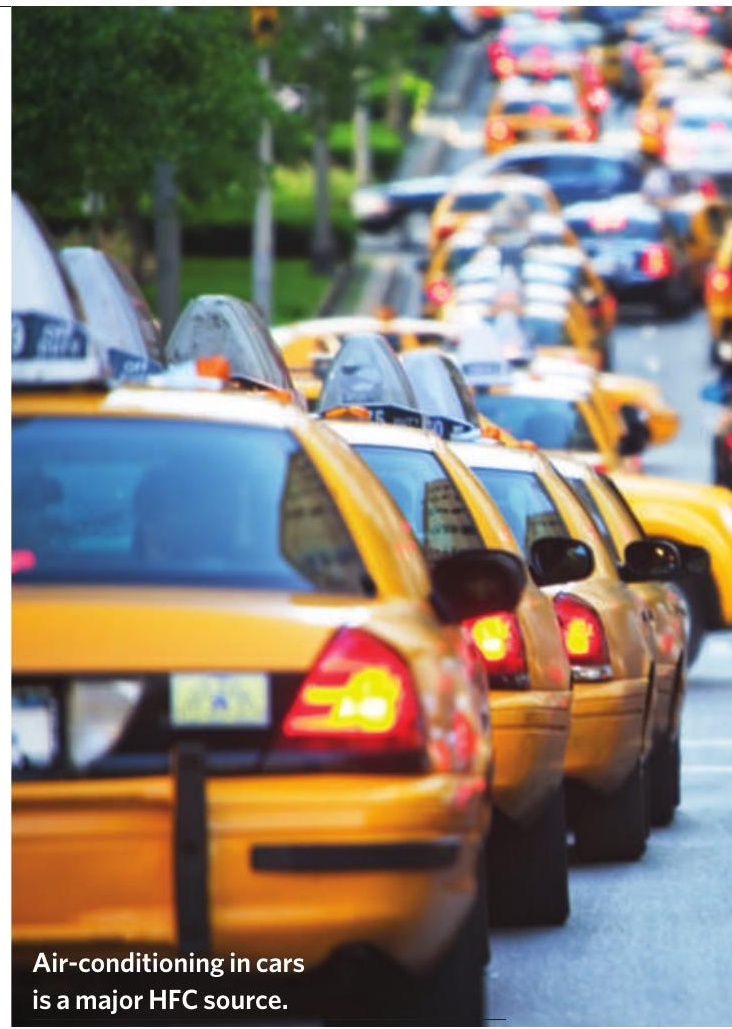

when they meet in Geneva next month.

Durwood Zaelke, who heads the advocacy group Institute for Governance and Sustainable Development in Washington DC, says the Velders study confirms the potential benefits of regulating HFCs under the Montreal agreement. It will, he says, help build momentum as the delegates move towards a decision in November.

\title{
Deficit dooms Swedish gene institute
}

Cost overruns have sliced into the historically important biology programme of Sweden's Lund University, culminating in a departmental reorganization that has some scientists fuming.

The Institute of Genetics, where in the winter of 1955-56 the correct number of human chromosomes was established (J. H. Tjio \& A. Levan Hereditas 42, 1-6; 1956), is being disbanded and four researchers laid off in a bitter reshuffle.

"Some researchers feel they can't afford to be nice to their colleagues," says Sven-Axel Bengtson, who directs the university's 274-year-old Museum

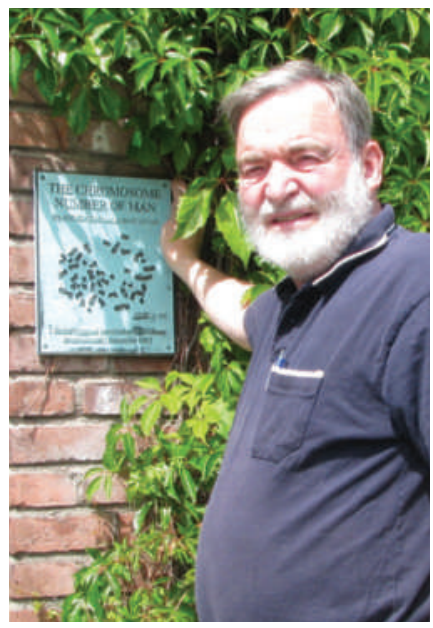

úlfur Árnason will lose his office. of Zoology. "When food is scarce, the horses will bite."

Acrimony peaked last week, when an emeritus professor was notified that he would lose his office by 30 June. Úlfur Árnason, who has been associated with the university for more than 50 years, was told he was to be ejected shortly after he sent a lengthy critique on the biology reorganization to the university's top executive, rector Per Eriksson. Árnason was among the few who openly questioned the proposal, contending it would undermine science at the university, reduce enrolment and cause revenue to drop further. $\mathrm{He}$ also noted that the vision group directed by zoologist Dan-Eric Nilsson, ranked 'outstanding' in a 2003 external review, was being cut, whereas a plant-research group criticized in the same review as being without focus was left largely untouched. Susanne Widell, who leads the plant group, is directing the biology reorganization; she did not respond to an interview request.

Árnason became an emeritus professor four years ago, as Swedish researchers do at age 67. Typically, such professors are permitted a university office if they continue research, as Árnason does. He is fighting the ousting. 
Terrabon, which uses technology developed at Texas A\&M University in College Station, plans to build a bigger plant in Port Arthur, Texas, that can process 55 tonnes of biomass a day, producing 4.9 million litres of fuel a year. It has applied for a $\$ 25$-million grant from the US Department of Energy to build this plant, but if it doesn't get the grant it will invest even more itself and make the plant even larger - to process up to 220 tonnes of biomass each day. If paying for the whole plant, says chief financial officer Malcolm McNeill, "you might as well go to the real size".

Meanwhile, the processing company UOP, based in Des Plaines, Illinois, has developed a pyrolysis technique that heats biomass to release oil. More work is needed to develop that oil into a fuel, but the technology is already being licensed by UOP's joint venture with Canadian company Ensyn Technologies in Ottawa, Ontario. "What this technology has lacked is the economic drivers to make it happen," says Graham Ellis, UOP's business manager for renewable energy and chemicals. UOP wants to help existing refineries to license its upgrading technology to use in existing infrastructure.

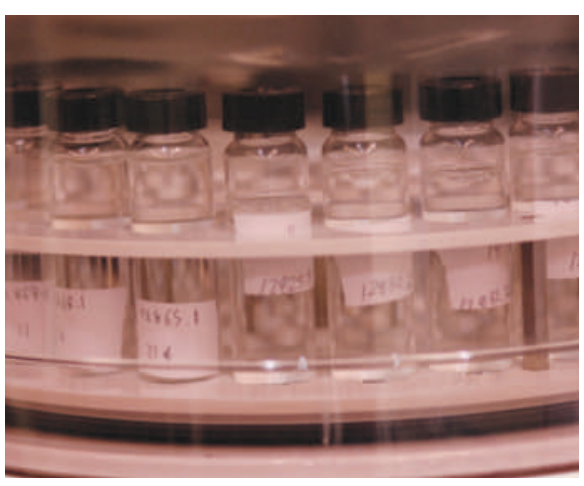

At Virent, researchers are engineering microbes to increase biofuel yield.

In Germany, the car-maker Volkswagen, based in Wolfsburg, is leading a €13.6-million (US\$20-million) project intended to eventually produce 200,000 tonnes per year of liquid fuels from biomass. The processing will be done by Choren Industries in Freiberg. Choren has separately amassed investments of $€ 140$ million, mainly from individual investors, although minority shareholders include Shell Deutschland Oil, Daimler and Volkswagen. It is now commissioning a new plant in Freiberg $\underset{\underline{\underline{u}}}{\stackrel{5}{\mathbf{s}}}$ that will have a nominal capacity of 18 million $\stackrel{\text { }}{>}$ litres of synthetic biofuel per year, all of which will be sold to Shell.

Some producers think they can eventually become competitive by offering a lower-cost product than many other first-generation biofuels. Raw-material costs for synthetic biofuels, says Choren spokeswoman Ines Bilas, can be around $40 \%$ of total costs, compared with nearly $90 \%$ for biodiesel made from rapeseed oil.

The fuel's adaptability may also help it to catch up with other, more established biofuel alternatives. "You really can make [petrol] from sorghum or municipal waste," says McNeill.

But for now, its future rests with process engineers and how well they can streamline the path from woody waste to liquid fuel.

\section{Katharine Sanderson}

\section{Correction}

The News story 'Climate burden of refrigerants rockets' (see Nature 459, 1040-1041; 2009) cited an incorrect year for when hydrofluorocarbon emissions were predicted to reach between 5.5 billion and 8.8 billion tonnes of carbon dioxide equivalent annually. The year is 2050 , not 2010. 